\title{
Wench Tactics? Openings in Conditions of Closure
}

\author{
Ruth Fletcher ${ }^{1} \cdot$ Diamond Ashiagbor $^{2}$ - Nicola Barker ${ }^{3}$. \\ Katie Cruz $^{4}$ - Nadine El-Enany ${ }^{5}$ - Nikki Godden-Rasul ${ }^{6}$. \\ Emily Grabham ${ }^{3}$ - Sarah Keenan ${ }^{5}$ - Ambreena Manji ${ }^{7}$. \\ Julie McCandless $^{8}$ - Sheelagh McGuinness ${ }^{4} \cdot$ Sara Ramshaw $^{9,10}$. \\ Yvette Russell $^{4} \cdot$ Harriet Samuels $^{11} \cdot$ Ann Stewart ${ }^{12} \cdot$ Dania Thomas $^{13}$
}

\begin{abstract}
Picking up the question of what FLaK might be, this editorial considers the relationship between openness and closure in feminist legal studies. How do we draw on feminist struggles for openness in common resources, from security to knowledge, as we inhabit a compromised space in commercial publishing? We think about this first in relation to the content of this issue: on image-based abuse continuums, asylum struggles, trials of protestors, customary justice, and not-sotimely reparations. Our thoughts take us through the different ways that openness
\end{abstract}

\begin{abstract}
The authors are the current members of the FLS Editorial Board, who have collectively produced this editorial as a collaborative research contribution, with Fletcher playing the role of primary author. More specifically, members have contributed to the editing and generation of the journal issue on which this editorial draws. Members of the Editorial Board were also involved in developing and participating in the programme for \#FLaK2016 infra n 2, on which this editorial also draws. Board members have discussed the policy issues, negotiations with Springer and response to Feminists@Law at FLS meetings and at our retreat in Glasgow in May 2017, and those discussions inform the editorial. Finally, we continue to think about this question of inhabiting institutional spaces differently and are delighted to be collaborating with the Centre for Research on Race and Law in hosting Sara Ahmed for our 25th anniversary lecture on 'The Institutional as Usual' on 6 October; see https://www.eventbrite.co.uk/e/ feminist-legal-studies-25th-anniversary-lecture-sara-ahmed-on-the-institutional-as-usual-sexism-tickets36747365359. Fletcher drafted the editorial and finalized it in light of comments from Board members.
\end{abstract}

$\triangle$ Ruth Fletcher

r.fletcher@qmul.ac.uk

1 Queen Mary University of London, London, UK

2 Institute of Advanced Legal Studies, London, UK

3 University of Kent, Canterbury, UK

4 University of Bristol, Bristol, UK

5 Birkbeck College, University of London, London, UK

6 University of Newcastle, Newcastle, UK

7 Cardiff University, Cardiff, UK 
and closure work in struggles against violence, cruel welcomes, and re-arrangements of code and custom. Secondly, we share some reflections on methodological openness and closure as the roundtable conversation on asylum, and the interview with Riles, remind us of \#FLaK2016 and its method of scattering sources as we think about how best to mix knowledges. Thirdly, prompted by the FLaK kitchen table conversations on openness, publishing and 'getting the word out', we respond to Kember's call to 'open up open access'. We explain the different current arrangements for opening up FLS content and how green open access, the sharedit initiative, author request and publisher discretion present alternatives to gold open access. Finally drawing on Franklin and Spade, we show how there are a range of 'wench tactics' - adapting gifts, stalling and resting — which we deploy as academic editors who are trying to have an impact on the access, use and circulation of our journal, even though we do not own the journal we edit. These wench tactics are alternatives to the more obvious or reported tactic of resignation, or withdrawing academic labour from editing and reviewing altogether. They help us think about brewing editorial time, what ambivalence over our 25 th birthday might mean, and how to inhabit painful places. In this, we respond in our own impure, compromised way to da Silva's call not to forget the native and slave as we do FLaK, and repurpose shrapnel, in our common commitments.

\section{Openings}

How does feminism enact openings and closings in conditions of violence? At FLS we have been mulling over this question since openness and open access provided food for thought at the closing kitchen table at FLaK. ${ }^{1}$ Feminism has a rich history of opposing enclosures and fighting to keep common resources open (Federici 2012; Kember 2014). And yet as the critical left reinvests in the commons we hear da Silva caution against a romantic recuperation of the struggle over commons, which foregrounds the European peasant and forgets the native and the slave (2016). With Alessandrini, and Desai (2011), we remember that the commons is never free of

\footnotetext{
1 FLaK is an acronym for our reflections on mixing feminism, legality and knowledges as we think about how best to value what has gone before in interdisciplinary and disciplinary approaches to feminist legal studies, while being curious about future possibilities. Earlier editorials have addressed what FLaK might be (Fletcher 2015a, 2016b) and FLS hosted the first FLaK seminar at QMUL on 30 June and 1 July 2016, see http://www.law.qmul.ac.uk/events/items/the-flak-seminar-mixing-feminism-legality-and-knowledge. html.
}

8 London School of Economics, London, UK

9 University of Exeter, Exeter, UK

10 University of Victoria, Victoria, Canada

11 University of Westminster, London, UK

12 Warwick University, Coventry, UK

13 University of Glasgow, Glasgow, UK 
power and its arrangements, but is terrain on which to struggle for different processes of valorisation.

We carry such thoughts around as we get on with the everyday tasks associated with publishing the journal. Does being attentive to an opening here and a closure there promise to make the violence otherwise? Our sights are set on grand transformations, but sight risks missing the tiniest of earth-shattering splinters if we only focus on the obvious tools. We worry about the gaps between our critical commitment to a commons of knowledge and our limited everyday practice in sharing feminist research.

In this editorial we share some partial answers to questions of what to do with that anxiety ${ }^{2}$ as we think about what feminist openness might be in conditions of closure. First, we answer by observing the content of this issue-on imagecontinuums, asylum struggles, trials of protestors, customary justice, and not-sotimely reparations-with a closing and opening eye. Reflecting on how these pieces help us think about our current preoccupations, pays tribute to our authors' contributions in the best way we know how. We also say something about the independent value of those contributions, in the hope of facilitating connections, and differentiations, for you our readers. Second, this editorial reflects on methodological openness and closure as the issue draws on different kinds of critical conversations in producing its content, and reminds us of \#FLaK2016.

How does looking back a year later help us think about FLaK as a thoughtful, multi-dimensional thing that we carry forward? ${ }^{3}$ If \#FLaK2016 was our first experiment with enacting an opening up of feminist legal methods by putting different, but particular, formats, experiences and knowledges in conversation with each other, could it have a multi-dimensional life of its own? ${ }^{4}$ If FLaK also provides an image of repurposed shrapnel, is it a useful image for thinking about what we do

\footnotetext{
${ }^{2}$ With thanks to Senthorun Raj for his comments on the importance of not flattening out anxiety at Feminist Reflections on Law, Society and Care, 21 July 2017; http://www.mmu.ac.uk/news/events/6297/ Accessed 30 July 2017. See also Mair (2017) citing Jivraj (2016, 83) over anxieties in law about children and the proper communities to which they belong.

${ }^{3}$ For one account of how we have carried forward some of the FLaK experience in illuminating our engagement with journal content, see Fletcher et al. (2016a). One way in which this editorial carries forward some of FLaK's questions about how best to enact methods which capture the multidimensionality of feminist legal studies, is with its table of contents. As in the FLaK2016 programme, this editorial's sub-headings run together to form complete sentences: 'Openings in conditions of closure' and 'Hesitating over open access in FLS policy and practice while feeding critical legal feminisms and deploying wench tactics'. This writerly practice of making sentences out of subheadings tries to be useful to participants and readers in allowing you to 'see' some of our key concerns quickly, and how they connect up with each other. The online formatting of the journal also allows you to navigate the different subsections as suits your interest. Engaging in such writerly practices is also a partial response to Kember's Why Write? (2016), as we think about how our writing might mix the limited formats of publishing technology, with keywords, and the desire for creative communication into some kind of useful guide. For an interesting project on 'useful' artistic interventions, where to be a-legal is to bend or sidestep law, see http://museumarteutil.net/about/.

${ }^{4}$ With special thanks to Lois Weaver for sharing her long table method (http://publicaddresssystems.org/ projects/long-table/), which we adapted for the kitchen tables, and to all the participants who joined FLS in helping to figure out what FLaK at the kitchen table might be, particularly Samia Bano, Doris Buss, Sarah Browne, Emilie Cloatre, Davina Cooper, Carys Craig, Moira Dustin, Mairead Enright, Mel Evans, Feminist Fightback, Annie Fletcher, Rosemary Hunter, Marie Andree Jacob, Jesse Jones, Sarah Kember,
} 
with feminist anger, discomfort, and joy? If here we answer our questions on openness with more questions, the final sections provide some particular kinds of answers by focusing on the FLaK kitchen table conversation on 'getting the word out'. In response to that conversation we discuss aspects of our editorial practice as we clarify FLS's current policy on open access and share some feminist hesitations (Lowe 2015) about complicity in openness as a condition of contemporary life. Finally we explain the 'wench tactics' - adapting gifts, stalling and resting-we deploy as academic editors seeking to influence the access, use and circulation of our journal, even though it is owned by Springer. These wench tactics are alternatives to the more obvious or reported tactic of resignation, or withdrawing academic labour from editing and reviewing altogether. They might also be useful for helping to think about inhabiting painful places and drawing on the expertise of the native and the slave in our common commitments.

\section{in conditions of closure}

In picking up Kelly's concept of the continuum of sexual violence and giving it new life, McGlynn et al. (2017) show how continuum-based analysis is a kind of technique of feminist opening and closing, even though they do not put it that way themselves. For Kelly, the concept of 'continuum' enabled a way of seeing connections between different practices of violence and addressing their interactive and cumulative effect (1988). A continuum is a continuous series of elements or events, which pass into each other and have a common character, even though they are often understood as disparate phenomena. For McGlynn et al., one use of imagery (e.g. upskirting) is opened up and connected with another (e.g. revenge porn) through the common character of the felt experience of sexualized humiliation. As the continuum of image-based sexual abuse assists the authors in making the case for joining up different fragments of humiliation, it also raises questions about how best to capture the unevenness of experiences of degradation.

The film 'I'd just like to be free', made by IMKAAN and the EVAWC 5 and shown at FLaK2016 by Moira Dustin, ${ }^{6}$ provides a beautiful, if painful example from Black British women's experience of sexual harassment. Here the women demonstrate the power of using the visual to talk back about the moments when gendered abuse turns racialised. Connecting experiences and placing them on a continuum opens them up for analysis, for intervention, for a changed experience. At the same time, continuum analysis and other feminist techniques also seek

\footnotetext{
Footnote 4 continued

Jane Krishnadas, Sonia Lawrence, Kristin B. Sandvik, Denise Ferreira da Silva, Speaking of I.M.E.L.D.A. and Karin Van Marle.

5 IMKAAN and End Violence Against Women Campaign, I'd just like to be free-young women speak out about sexual harassment, March 2016, available to view here: https://www.youtube.com/watch?v=1JqpvibpdU. Accessed 30 July 2017.

${ }^{6}$ Dustin was then Director of Research and Communications at the Equality and Diversity Forum, and is now a Research Fellow at the Department of Law, University of Sussex.
} 
closures. They try to close off the paths that hurt by sensationalizing, disbelieving and over-scrutinizing the experiences of those seeking escape from violence.

The conversation orchestrated by Samuels and the Westminster Gender, Sexuality and Law Group on women and asylum drew on feminist techniques of connecting experience and expertise in order to open up possibilities of being otherwise (2017). This roundtable practiced a well-rehearsed feminist point about bringing the subjects to the table. But it is a point that sometimes gets overshadowed as feminism speaks to different kinds of audiences and as feminist methods get mainstreamed. The mix of legal knowledges, which the participants displayed, is another key aspect of feminist legal programming that we could make more explicit in contesting the linear understanding of how knowledge impacts. There is a comfort to the persistence of these feminist, collaborative, 'start where you are' research techniques as they ask legal actors of different kinds to share knowledge from their practice. But that comfort may underestimate the careful preparation that goes in to generating a seemingly open conversation while ensuring enough difference and not too much airtime. As we watch these kinds of feminist collaborative research techniques be born again as roundtables, long tables, kitchen tables, caucuses ${ }^{7}$ and workshops of various kinds, they help us think about how to make critical legal participation routine in its multiplicity.

Those with experience of the asylum process-refugees, lawyers, educatorsshared their knowledge in order to open up understanding and tactics of challenge. The audience at the Westminster conversation clearly saw the absurdity in the gap between treatment of violence against women in an asylum context and that in a domestic context. How could feminists and gender and sexuality activists best engage the Home Office and other relevant actors in the conversation that had developed around understanding coercive control and sexual violence? As Singer asked (Samuels 2017) and as the Protection Gap Campaign ${ }^{8}$ is demanding: "If a victim of crime in Europe has a right to these things - to be interviewed by a woman, without your family or children present, by officials who are appropriately trained, and to have counseling and information available - then why not a woman who is claiming asylum here?".

The cruelty of some openings as they hold out the possibility of welcome, only to snatch it away again, was also obvious in this conversation. As Solanki explained, one judge declared that he believed the woman asylum-seeker and found her a completely credible witness, only to go on to find that her connection to her apparently not-so-credible husband was fatal for her (Samuels 2017). Her own reasons for flight became invisible and legally ineffective as the fact of her marriage to another asylum seeker became the lens through which her claim was evaluated. The asylum opportunity opens up almost in order for the official to be affirmed as the one who has the power to close it down again. There is clear potential for these

\footnotetext{
7 See further: Becoming More, a ten day caucus comprising of lectures, performances, screenings, commissions, discussions and food hosted by the Van Abbemuseum, Eindhoven, convened by (FLaK participant) Annie Fletcher, 18-28 May 2017. https://vanabbemuseum.nl/en/programme/programme/ becoming-more/.

8 See further http://www.asylumaid.org.uk/protectiongap/.
} 
feminist insights into 'cruel welcomes' to illuminate critique and activism around the detention of migrants more generally. ${ }^{9}$

Kondakov's paper approaches the significance of opening up legal knowledge and participation through critiquing the response to one of Pussy Riot's protests (2017). Their performance of this 'punk prayer' in the Moscow Cathedral of Christ the Saviour, which exhorted the Virgin Mary to become a feminist and help unseat President Putin, lasted less than two minutes but was seen by millions around the world. This 'short, sharp shock' (Mayer 2013) developed into a series of court cases and contested the repressive force of the Kremlin under Putin and the equation of Putin's homonormative masculinity with national strength. Johnson has argued that Pussy Riot are part of a growing informal feminism in Russia, which is responding to the repression of feminist NGOs and saw feminists march in their own column in an October 2012 protest for the first time in post Soviet Russian history $(2014,587)$. Pussy Riot were treated particularly harshly in Johnson's view because their overt defiance violated the political 'cleaner' role $^{10}$ that has been assigned to elite women in recent Kremlin history. As Tyler has reminded us elsewhere (2013), understanding the citational history of feminist protest is one key way of tracking the deployment of legal knowledge towards building another world. Pussy Riot draws on a gendered history of Russian revolution and the past presence of women revolutionaries as they characterise Putin's authoritarianism as a form of patriarchy.

Kondakov focuses on the significance of Pussy Riot before the court as Maria Alyekhina, Nadezhda Tolokonnikova and Ekaterina Samutsevich were tried for 'hooliganism' under Article 213 of the Russian Criminal Code, found guilty and sentenced to two years in prison. His analysis shows how the rules of the Russian Orthodox Church and the criminal law interact to collapse distinctions between Russian society and orthodox believers in order to justify the invocation of the criminal law rather than administrative discipline in policing gendered citizenship. As the judge represents Russia as already egalitarian, Pussy Riot's feminism is seen as both unnecessary and a social threat in promising the destruction of traditional familial and sexual relations. At the same time, the failure to observe gendered dress and behaviour norms in church is represented as a threat to social order and a form of hooliganism. Pussy Riot's feminist and artistic commitments are delegitimated in a series of rhetorical claims which represent them as fraudulent and untrue. Since the legal process does not hear from the women prosecuted on their own terms, Kondadov responds by producing and discussing Ekaterina Samutsevich's

\footnotetext{
9 At FLaK2016 we heard from Sarah Keenan about the London based protests over the deaths and harsh treatment of migrants detained in Nauru and Manus by the Australian government, see further Davidson (2016) and El-Enany and Keenan (2016).

${ }^{10}$ In an interesting connection to the way the figure of the cleaner circulates, Speaking Of Imelda drew on the role of Irish cleaners in their performance at FLaK2016, as they grounded discussion of abortion restrictions and common knowledge of abortion practice in exchanges between cleaners as they worked. As we think about the regulation of domestic labour and all kinds of cleaner tasks there is significant potential to recuperate the figure of the cleaner as a feminist knower. See further: Blackett (2016), whose sources for documenting formal and informal domestic work and its regulation, include cookbooks, available here https://www.soas.ac.uk/law/events/27jul2016-whats-informality-got-to-do-with-itdomestic-work-the-employment-relationship-and-social-j.html. Accessed 30 July 2017. For more on the regulatory environment see Ashiagbor 2006 and Blackett 2011.
} 
biographical narrative. Her story is narrated as a series of institutional pressures, which limit her life opportunities and form her resistant subjectivity, leading to an encounter with modern art and her first sense of deliberate, chosen, self-expression.

For Kondakov, the legal documents reveal repetition, a lack of rigour, and poor engagement, as law performs a violent closure and sentences the women to two years in prison. But since the subject 'has no choice but to resist' in such conditions, repression also opens the path to more resistance, as demonstrated in the life story of Samutsevich. Spade has argued (referring to 'law reform' where we would add 'litigation') that: "In the face of significant resistance to conditions of subjection, law reform tends to provide just enough transformation to stabilize and preserve status quo conditions" $(2011,459)$. While we think it is important to be alive to that likelihood, practices within reform, litigation, protest or programming also carry the possibility of being otherwise. At FLaK2016, da Silva shared with us some of her work on 'Hacking the Subject' (2015), as it draws on Hortense Spillers' reconfiguration of 'woman' to disorder the modern grammar of the patriarch. We accept Spade's caution about how re-arrangements may maintain rather than disrupt the status quo. But we find shelter and sustenance in da Silva's example of rethinking grammar, as we try to work through what certain changes to 'legal code' might mean. ${ }^{11}$

Dunn's study of baraza employs feminist fieldwork towards the identification and understanding of customary justice mechanisms, rather than parliamentary and court based modes of seeking legal redress (2017). Her inquiry takes her to South Kivu in the Democratic Republic of Congo as a site of transitional justice where extreme and ordinary violence have lived side by side. Dunn's documentation of custom sits alongside continuum analysis and table conversations as a kind of knowing practice that intervenes in the reproduction of life. As a lineage of feminist critique, documenting custom pluralises law and its effects by moving beyond what might seem the obvious legal institutions. Criticising custom also brings with it a commitment to working with local expertise in naming and countering gendered harms (Stewart 2011). From resisting the colonial contempt with which the local residents of Grenfell have been treated (El-Enany 2017b), to lining the walls of law schools differently, ${ }^{12}$ critical strategies seem to demand a re-engagement with local custom.

Dunn also contributes to a feminist critique of transitional justice for being overly focused on 'extraordinary wartime violence' at the expense of addressing the ordinary everyday violence that also makes transition necessary (see also Gallen 2017). Baraza was traditionally a gathering of people with the purpose of addressing a problem, usually an interpersonal conflict. A local NGO, FOCHI, decided to revitalise baraza with the use of community recommended mediators. They wanted to respond to the known potential for everyday conflicts to turn violent given the lack of trust due to war. Baraza has three levels with the first involving a response

\footnotetext{
11 As Mary Shine Thompson (2017, 67) and Margaret Davies (2012) bring out in different ways, feminist judgments projects are about the coding of judgment and how to pass as a judge.

12 Nikki Godden Rasul shared her experience of co-organising the Inspirational Women of Law exhibition at FLaK2016; see http://www.iwlaw.uk. Accessed 30 July 2017.
} 
by two mediators, the second a response by a committee of four mediators, and the third a public reconciliation ceremony between victim, perpetrator and community members. As Dunn addresses three sites of everyday harms against womendomestic violence, polygymous relationships and witchcraft - she finds that baraza achieved measures of (1) women's participation in transition, (2) justice for harms against women, and of (3) advancement in gender equality. Although clearly far from perfect, baraza "allows women to participate largely on their own terms. It is free, locally accessible and familiar."

While image-continuums, asylum struggles, protest and baraza provide a view into the conditions of violent harm that close down people's lives, Riles and Welsh remind us that closures can be something else (Welsh 2017). As they discuss time, form and the settlement in the case of the Comfort Women, Riles says: "certain kinds of closure are actually productive and generative and actually good things for women." This idea that some kinds of closure are good reminds us that closing techniques might have a role to play in struggle towards a different, more feminist, process of valorising the commons. Certainly feminists have good reason to be wary of calls for a kind of continuous opening. Being continuously open risks depleting the very bodies we need to sustain critical engagement (Rai et al. 2014).

\section{Hesitating over open access}

These feminist hesitations ${ }^{13}$ about openness extend to open access policy and practice. As FLS editors, our expertise in publishing is experience-based in the first instance. We find ourselves drawing on feminist methods of reflexivity and contextualization as we develop that expertise and intervene in the world of academic journals (see further Gunaratnam and Hamilton 2017). When we planned FLaK2016, a significant part of our motivation was to turn our frustrations about the publishing environment into something critical. We wanted to think more deeply about the particular challenges of open access policy, without getting too specialized or technocratic. We also wanted to think critically about our place within the global publishing machine, while taking a bit of feminist space with us, as Keenan (2015; 2017, 150-170) would say.

FLaK2016 responded to these wants by plotting a course towards a kitchen table on publishing and open access, which would take us through a range of feminist conversations. ${ }^{14}$ In constructing the programme in this way, we were juggling a number of critical feminist aims, only some of which we'll address here. We scattered ingredients of abstraction and concretization through the programme from different kinds of sources. This was partly an alternative to the more usual way

\footnotetext{
13 Here we are drawing on Lowe's sense of hesitation, which is not "inaction or postponement, or a thwarting of the wish to provide for a future world. Rather, it halts the desire for recognition by the present social order and staves off the compulsion to make visible within current epistemological orthodoxy" $(2015,98)$.

14 There is more to be said and done about 'improvisation' in academic event programming and how it cultivates a kind of contrived intellectual spontaneity. For one touchstone of our thinking in this regard see Ramshaw (2010).
} 
of organizing academic programmes in a linear fashion and working deductively 'down' from key concepts or inductively 'up' from key practices. But it was also a way of building and reflecting on feminist critical method as it has developed different dimensions of working through practice, including theoretical practice. We wanted to recognise, and revive if necessary, a feminist intellectual lineage of theorizing from practice and experience based expertise, but in ways which learned from critiques too (Brown 1993). The aim was to make space for experiential modes-not to privilege them as the most authentic knowledge-by placing them among the sources of conversation. ${ }^{15}$ But we wanted to make space for theoretical experimentation as well. So the programmed scattering of ingredients at the different kitchen tables sought to include experience and practice based thinking, facilitate possible connection between or reframing of differently situated work, and allow for theoretical reflexivity.

Our publishing experience is so mired in everyday mundane activities and so constrained by the world of global capitalism, that making space to think about it critically is difficult, especially when lots of other things seem more significant. From a programming perspective it was important that the publishing kitchen table come at the end of the two days, and that the other tables prepare us for that. But each table had to stand on its own too in taking stock and tackling a range of concerns including decolonizing techniques and enacting dissent. And of course we had to leave some time and space for the unexpected. ${ }^{16} \mathrm{We}$ could not anticipate in advance which aspects of the conversation would engage the audience, and how they would do so. But we hoped that this scattering would allow the FLaK conversation to pulse intensely at times, to rest at others, and to respond as necessary.

Dania Thomas, Carys Craig, Rosemary Hunter, Marie Andree Jacob and Sarah Kember provided the starting contributions at FLaK's closing kitchen table on 'getting the word out'. Thomas began by situating the open access question as a pressing one for Feminist Legal Studies given our desire to make critical connections through open distribution while not being in control of the terms of our operation as a Springer-owned journal. Craig reflected on shared commitments and challenges for critical feminist movements and open access initiatives, and

\footnotetext{
15 McCandless et al. talk about the particular methodology of their feminist judgments project being devised so as to "hear these [local cultural and political] struggles and interventions [from activists and artists] so that they might come to 'trouble' the cases to be rewritten" $(2017,15)$. The FLaK method of scattering sources builds on a similar feminist commitment to hearing from and listening to different kinds of legal participants, but less in response to a lack of published sources thereon, and more as a result of wanting to recognise different sources of critical thinking.

${ }^{16}$ FLaK was a week after the Brexit vote and we were all distressed and challenged about its significance. The mood made a difference to the conversation and to the general willingness to go with the experimental kitchen table format as various people dissented from coming to the table to speak. This helped us think about the conditions that produce dissent, and how to give space to each other's hurt and grumpiness, while also asking for respect, co-operation and solidarity. In one more particular instance of how the Brexit context changed our programme in unexpected ways, the first kitchen table starter contributor, El-Enany, asked her audience to engage in a 'referendum'. They were to decide whether she should speak to her work on the institutional racism of the decision to void Lutfur Rahman's re-election as Mayor of Tower Hamlets (2017a), or on the Brexit campaign as nostalgia for empire (2016). The audience chose the Brexit topic.
} 
suggested that feminists could explore the relationship between access and agency, openness and freedom, by changing our 'table manners', educating about copyright/ left, and developing clear and thoughtful practices around attribution, citation, and acknowledgement (see further Craig et al. 2011). Hunter shared her experience of editing Feminists@Law, ${ }^{17}$ a 'platinum' journal which is fully open access, does not charge authors for publishing and is produced using voluntary academic labour and open source technology. The mimicry of 'fake journals' made an appearance in Jacob's comments as she encouraged us to think about the significance of their use of publishing conventions (see further 2017). Kember, director of the newly established Goldsmiths Press, drew on long-standing feminist critiques of hidden, unpaid labour to suggest that we should be wary of an open access agenda, which claims to be open in the same way that free markets claim to be free (see further 2014, 2016).

As the dialogue about publishing was joined by others from FLS and the FLaK audience, it was marked by moments of surprise, frustration and illumination. There was a general sense of incredulity at the complexity of publishing, particularly but not exclusively from those less familiar with the dynamics of academic journals. Although people had partial knowledge of their particular patch of publishing, as authors, editors and bloggers, they were able to get on with it without an overview of the field. As the delights of 'green', 'gold' and 'platinum' open access, the intricacies of metrics, and the diversity of publishers were discussed, there was surprise and fascination at the way the terrain had been carved up.

Fascination turned into frustration as those relatively new to academic publishing asked how they were supposed to navigate the politics of publishing given the multiple pulls on their time and energy. Those who had been around for longer were frustrated by other aspects, such as failures to value hard won battles over improvements. But some of the more interesting moments (for some of us at least) occurred as feminist practices emerged to illuminate a way through. There was a comfort in recognizing how techniques which sustain in other feminist contextsthe importance of not turning everything into a measure of productivity, keeping space for creative play, and bringing the hidden labour out of the shadows-could be adapted for engagements with publishing.

Reflexive critiques with which we had engaged over the two days re-appeared in a slightly different guise as we wondered how they might apply. One example was how Cooper's contribution at her kitchen table resonated at this later moment in the programme. She had shared her critical thinking on the problems with withdrawl and boycott-type strategies in considering the significance of conservative religious refusals to engage over issues of sexuality (see further Cooper 2015). Instead she had encouraged us to think about being 'ever-present' to each other so that we might imagine and actualize critical engagement. In response to Fletcher's prompt that the table re-engage with these ideas about withdrawl and their critique, Kember noted that some researchers of publishing have counselled that academics could be more

\footnotetext{
17 See further: http://journals.kent.ac.uk/index.php/feministsatlaw. Interestingly, one FLaK2016 participant referred to Feminists@Law as a 'pop-up' journal, as the kitchen table conversation made connections between institutional forms from theatre to publishing houses.
} 
willing to hold publishing houses to account by withdrawing their labour (Deazley and Mathis 2013, 28). But in establishing Goldsmiths Press using green open access mechanisms, she had decided to invest instead in developing the public universitybased infrastructure which could link up academic research through a searchable system of public repositories. Others noted the importance of feminist habitation of publishing spaces, including the corporate for-profit sector, in order to keep publishing channels open and share information and strategy across publishing sites. In other words, the conversation identified a range, a continuum if you will, of activities that might, and do, press ${ }^{18}$ on different dimensions of contemporary publishing practice and its modes of organising.

We've been thinking about this anew in response to a recent editorial by Feminists@Law (Hunter and Alessandrini 2017). On their fifth anniversary they have restated their opposition to gold open access policy and expanded it to include opposition to hybrid open access. ${ }^{19}$ This puts us at Feminist Legal Studies in an interesting position. We have considerable sympathy with their call for policy levers to be used against hybrid journals, given that the publishers of these journals are over-earning through subscriptions and pay-to-say fees or Author Processing Charges (APCs), and making research difficult to access, as we discuss below. But $F L S$ is a hybrid journal, even if that is not all that FLS is. The FLS editorial board cannot support a call for public funding to be withdrawn from research that we publish in this moment in time, not least because we work hard to contribute to the development and dissemination of that research. But more importantly for now, we are concerned that calls like this risk erasing the significance of feminist presence within hybrid journals.

While we all work towards making our publishing environment more equitable and sustainable, we think it is important to maintain $F L S$ as a critical international network with a distinctive research reputation, a 25 year history and a global distribution machine. Researchers and research benefit from access to that network. More than that, FLS editors are committed to a critical future. As feminists have long argued, the resources we need for that future are not reducible to cashflows, policy support and technological infrastructure, even if these are vitally important components. Time, energy and expertise are also needed-on their own terms and in their relation with cashflow, policy and technology-for future actualization of a commons of knowledge. There is expertise to be gained about how publishing works, and might work differently, from our participation in the commercial publishing sector, even if that participation is a historical accident (Lamble 2014). We might be highly sceptical about our ability to influence that sector, but we have to work from where we are. It is important to maintain and grow feminist space in large hybrid publishers, while also pushing externally for a more feminist approach to publishing policy and the knowledge commons. Therefore,

\footnotetext{
18 With Sara Ahmed $(2004,6)$, we "remember the press in an impression. It allows us to associate the experience of having an emotion with the very affect of one surface upon another, an affect that leaves its mark or trace".

19 Hybrid open access combines gold open access options with green open access options, and subscription models where the reader pays, with online access models where the author pays; see below for a fuller explanation.
} 
prompted by what we have learned from FLaK conversations, and by a sense that we can contribute to the 'opening up of open access' as Kember would say (2014), the next section clarifies the different current arrangements for opening up FLS content.

\section{in $F L S$ policy and practice}

As a Springer Nature hybrid journal, FLS comes in two forms of open access, one gold and one green. The gold standard, 'Open Choice', ${ }^{20}$ makes the full research publication directly available to the reader on a journal webpage, which is usually identifiable by a DoI number and a link, or can be searched out through research indexes and internet search engines. Examples of gold open access publications in this issue are: McGlynn et al. (2017) and Welsh (2017). The author retains copyright $^{21}$ in the publication, rather than transferring it to Springer as in the traditional subscription model, and can post and share that publication as she likes. The catch is that publishers charge significant Author Processing Charges (APCs) for this mode of making research accessible to others.

Springer's current APC is €2200 euro (excluding VAT) per publication for the service of having your own research disseminated openly by the journal's publication machine. This charge is similar to that charged by other equivalent publishers. Obviously researchers are not likely to pay such sums out of their own pockets. Rather they depend on access to research fund subsidies in order to cover the cost of APCs and make their research freely available. ${ }^{22}$ At present, post Finch report, ${ }^{23} \mathrm{UK}$ research policy is very supportive of open access research. Publicly funded universities and research councils usually provide employees and researchers, with the funds to cover APCs. But there are significant questions to be asked about whether payment of substantial APCs to commercial publishers with little or no accountability for the charge is the best use of public funds and the best means of achieving open access goals (Kember 2016; Hunter and Alessandrini 2017). In the UK, not all universities have access to such funds for their employees, and lots of research is conducted for the public benefit without having funds to cover the costs of APCs. International journals like FLS also want to publish work produced in jurisdictions where there is little or no local funding available to cover

\footnotetext{
${ }^{20}$ See http://www.springer.com/gb/open-access/springer-open-choice.

21 FLS's copyright licence is currently the CC-BY licence https://creativecommons.org/licenses/by/4.0/. This licence permits unrestricted use, distribution and reproduction in any medium, on condition that appropriate credit is given to the original author(s) and the source, a link to the Creative Commons license is included, and it is indicated if any changes were made. Some Springer journals use the CC BY NC licence, which only allows use, distribution and reproduction for non-commercial purposes. Kember makes the point that openness should also involve the removal of copyright restrictions, but that copyright restrictions will mean different things to different publishers (2016). Small independent publishers might need copyright restrictions on their publications in order to survive, while the big corporate publishers have done all too well out of copyright.

22 See here for Springer's explanation: http://www.springer.com/de/open-access/open-access-funding.

23 Working Group on Expanding Access to Published Research Findings ('Finch Group') (2012); available here https://www.acu.ac.uk/research-information-network/finch-report Accessed 30 July 2017.
} 
the cost of 'gold open access' research. Gold open access policy risks generating new research enclosures, if those who have research funds get privileged access to publication. It also risks exacerbating existing global inequalities in research participation and use, as knowledge flows away from sites with poorer research infrastructure. $^{24}$

As well as acquiring fees from the public purse, publishers like Springer also draw down significant amounts of free or publicly subsidized academic labour. Academics edit and review voluntarily, and journals depend on this labour to function. One study has calculated that peer review labour was worth $£ 1.9$ billion to the journal publishing industry in 2007 with an annual revenue of 4 billion (Research Information Network 2008; Deazley and Mathis 2013). As Jacob pointed out at FLaK2016, so-called 'fake journals' are good at mimicing these editorial and review processes (see further 2017 forthcoming). They send out emails fishing for publications. Their mimicry emphasizes the empty formality of these conventions, and provokes us to ask how we might best value and use our own customary practice and unpaid labour as we contribute to the reproduction of knowledge. The performance of openness through gold open access policy brings a kind of openness into being that foregrounds the needs of the user/reader while redistributing significant public funds and unpaid labour to the commercial publishers. This kind of openness also consolidates and expands significant inequalities in global knowledge production, since access to public funds and disposable academic labour is so uneven. ${ }^{25}$

Gold open access is not the full story about access to FLS publications however. There are a number of other paths by which readers can arrive at FLS content, even when it is copyrighted by Springer and normally requires a subscription or fee. Springer provides two policy options, 'green' open access and the SharedIt initiative, which enable the reader to access publications without paying a fee. Through reliance on 'self-archiving' the green route enables researchers to share publications without paying a charge. Green open access secures research availability by making indirect, conditional access to publications possible. ${ }^{26}$ The basic idea is that authors are permitted to make a version of their published paper freely available online, but the publisher-provided and copyrighted version remains behind a paywall. Green open access facilitates a parallel system of alternative free sources. These free sources do not bear the markings of the publisher's formatting and are not directly available from the publisher, but have more or less the same research content. They have location and time restrictions and information requirements.

Prior 'work-in-progress' versions of FLS published articles, which were published on non-commercial pre-print servers before acceptance by $F L S$, may

\footnotetext{
${ }^{24}$ On a related issue about the problematic double counting of research monies as development aid in the UK, see Manji and Mandler (2017).

${ }^{25}$ See further \#OpenGlobalSouth and the programme for 'An Open Digital Global South: Risks and Rewards, UC Davis', 25-26 May 2017, available here: http://icis.ucdavis.edu/?tribe_events=opennessand-the-global-south-new-access-or-new-exclusions. Accessed 30 July 2017.

${ }^{26}$ You can read the full set of conditions https://www.springer.com/gp/open-access/authors-rights/selfarchiving-policy/2124.
} 
remain on those servers and/or be updated with the author's accepted version. If the author self-archives the 'accepted manuscript' version of the article on the author's own website after official publication, there is no time restriction or embargo period. Accepted manuscripts may also be distributed via 'any repository', usually a university repository, but only after 12 months from the date of official publication. When Springer has the copyright, the final published version usually in the form of a Springer PDF file, may not be shared on sites other than the publisher's official website. In terms of information requirements, the self-archived or deposited versions must acknowledge the original source and include a link to the published article and the DOI number. ${ }^{27}$ Green open access enables readers and researchers to get over pay barriers, but it generates other barriers through conditionality and complexity. ${ }^{28}$

The SharedIt initiative provides a freeview option for Springer publications, including those copyrighted by Springer. When the article is published and copyright is transferred, the publisher sends the author a shareable link to a viewonly version of the paper. There are no limits on the sharing of this link, and many of our authors are sharing their papers across social media, websites and institutional repositories (e.g. Cobb and Godden-Rasul 2017). While Springer makes the view-only format available using ReadCube tools, it is up to the author to share the link with readers, as it is with green open access. At FLS we are keen to disseminate these view-only links and green open access sources via the @FLS_Journal twitter account, but at the moment we depend on authors sharing them with us in the first instance.

Otherwise, there are two other 'informal' paths by which readers can access FLS subscription based content. Authors are permitted to share their own publications on request for non-commercial purposes, and are usually keen to do so. Sending an author a request for a copy of her publication is a tried and trusted means of accessing research and encourages research contact even if it might also use up time. Indeed UK research policy and practice is currently making more of the author request mechanism as a means of distribution. In order to comply with UK research audit rules on green open access, authors have to deposit their research publications in institutional repositories. Like most publishers, Springer also exercises discretionary powers over making copyrighted content available usually for promotional purposes. This discretion currently takes the form of making our editorials open access and of making three editors' choice articles freely accessible for a period of two months.

As a result there are four different pathways by which content that is normally restricted to fee-paying or subscription-holding readers, is made available at no charge. Green open access, sharedit, author request, and publisher discretion all

\footnotetext{
27 The suggested wording for such an acknowledgement is: "The final publication is available at Springer via http://dx.doi.org/[xxx]".

28 Goldsmiths Press is an interesting example of a university initiative which is using green open access to generate an alternative to the big publisher pay-to-say gold open access, and to the corporate sharing platforms like Academia.edu "by placing work in searchable archives and repositories that will, hopefully, one day link institutions and generate a diversity of research commons." See http://www.gold. ac.uk/goldsmiths-press/.
} 
provide access to research content. The difficulties are that sometimes these mechanisms do not work, and they take information, time and energy to figure out. But they do provide us with some resources for critical and creative engagement in opening up the journal's world, or finding cracks in the enclosures as O'Donovan (2014) and Harraway (Gane 2006, 147) would have it. There are things we can do to narrow, if not close, the gap between our commitment to a feminist commons of knowledge and our current position as a reluctant gate-keeper. If publishers are already spending time and energy on making these alternative options available, and if easier 'gold' type access increases or diversifies use, then we should be adding pressure to make gold access significantly cheaper and more actually usable for authors and readers.

\section{while feeding critical legal feminisms}

Being here is significant. FLS presence makes it possible for that interested student, isolated academic or curious reader to connect up with a world which valorizes legal knowledge differently. We are obviously not alone in that, but populating libraries, indexes and websites with FLS continues to be important in feeding critical legal feminisms. Being counted as having research impact can also be a useful tool in getting feminist research recognized and valued by employers, funding bodies and curious readers. We join with other critical scholars and with arts and humanities disciplines in being deeply sceptical about the significance of metrics as a way of measuring research value. But we do not discount the significance of metrics and 'being counted' as a form of knowledge about research. If the fact that FLS's impact factor has grown to 1.130 in 2016 helps an individual researcher get institutional support for publishing her work, then it has helped to expand research boundaries. $F L S$ is a compromised hybrid space within the world of research, but inhabiting that space and finding more ways to make it usable by legal feminists of all kinds, matters.

Becoming more of a feminist commons is not down to us since Springer owns us. But again we can learn from others who do not own the products of their labour nor the means of production, and from theorizing about opening up ownership and bedding down other ways of belonging (e.g. Cooper 2007; Keenan 2015). ${ }^{29}$ We may even be able to bring the figures of the slave and the native back into our critique and contestation of the knowledge enclosures we inhabit, in a partial response to da Silva (2016). Petchesky is among those who have shown us the potential for feminism to revision ownership through an appreciation of how slaves found ways to claim self-ownership, "but always embedded in the communal context of the suffering of other slaves and their efforts to achieve freedom" (1995, 399). Biagioli has shown us how the figure of the kidnapped slave plays a role in constituting plagiarism as a form of academic misconduct and a kind of kinship relation between author, work and readers (2014). We can draw from slave narratives, accounts of

\footnotetext{
${ }^{29}$ Mair's review (2017) of Jivraj's work on children's racialised belonging, in this issue, is also relevant to capturing different subjects and modes of belonging.
} 
native belonging (Watson 2015) and other sources of struggle to claim worth in circumstances where worth is denied, as we figure out ways of making our own of journal accessibility, while keeping feminist connections in mind.

Of course such an approach needs to be careful not to erase important differences. But with Lowe $(2015,89)$ we think it is important to find ways to unsettle the "processes through which the human is universalized and freed by liberal forms, while the people who created the conditions of possibility for those freedoms are forcibly assimilated, or forgotten." It is in this spirit of not forgetting, and moreover critically working with such struggles out of certain kinds of ownership, that we seek to draw inspiration for developing our own decolonizing techniques in our everyday editorial practice. Having the journal owned by Springer does not prevent those of us editing the journal, from seeking to make arrangements with the owners as we constitute different kinds of editor kinship, to adapt Biagioli. Academic expertise and reputation are fundamental to the value of the journal, but cannot be properly maintained without the participation of academic experts. Perhaps there are ways we can use our collective academic belonging to hold publishers to account.

As Franklin has argued, being a 'wench in the works' is one kind of strategy that is open to us as academics participating in the reproduction of knowledge in universities and publishing (2015). Could editors use the time-honoured strategy of 'being difficult', with all the caveats that some will be seen as more difficult than others, and refuse to go along with Springer processes and instructions? And if so how might we assess the effect of such refusals as we go along? Feminist protest has a rich tradition of success with 'being difficult' in calling attention to patriarchal problems and disrupting their routine acceptance, some of which has featured in FLS pages and events (Mulcahy 2015; Enright 2014; Feminist Fightback 2011; Speaking of I.M.E.L.D.A. 2015; Kondakov 2017). But we also hear Sara Ahmed (2014) and other feminist killjoys warn of strong, sharp reaction, as those who call attention to the problem, become the problem. Here we draw on Franklin's wench (2015) and Spade's tactics (2011) to ask how 'wench tactics' might recognise a context of multiple and competing goals, move beyond taking the master at face value, and look at how we might disrupt and change the arrangements that concern us.

\section{and deploying wench tactics}

The tactic which seems the most disruptive is to draw from feminist strike actions (e.g. Enright 2017) and withdraw our labour altogether, a possibility which is discussed in relation to academic labour on journals by Ronan Deazley and Jason Mathis (2013). Some journal boards have done this in the past ${ }^{30}$ and resigning en masse is certainly not completely off the table as a future option. But use of the

\footnotetext{
${ }^{30}$ See further https://www.insidehighered.com/news/2015/11/02/editors-and-editorial-board-quit-toplinguistics-journal-protest-subscription-fees and https:/www.elsevier.com/connect/addressing-theresignation-of-the-lingua-editorial-board.
} 
resigning tactic is a fairly drastic move and would usually mean that the title would stay with Springer, while the academic editors go elsewhere. In Lingua's case, the six editors and 31 members of the editorial board, resigned in October 2015 over Elsevier's refusal to meet their demands on a lower APC, the right for authors to retain copyright over their own work, and ownership of the journal (Jaschik 2015). Rooryck and other editors went on to establish Glossa, ${ }^{31}$ an online journal with an APC of $\$ 400$, rather than Lingua's $\$ 1800$, but Lingua continued on under new editors. ${ }^{32}$ As Heyman and colleagues argue in relation to another withdrawl-type tactic used against Elsevier in the form of the Cost of Knowledge petition (2016), it is difficult to assess the sustainability and effects of such actions, even if they clearly have some impact. We think that it is worth thinking about other kinds of 'wench tactics'.

With our editorials over the last two years, we have taken the promotional online space that Springer provides and filled that space with knowledge about the content and processes of the journal, and passed it on to you, our readers. Springer provides editorial space as if it was an open access space. But they retain the copyright and they do not charge us for making it open access, so editorials are not formally gold open access spaces. Perhaps it is a mark of how bad things are in academic publishing that we are almost grateful for this promotional 'gift' of free online space in the journal, which we spend weeks editing. But 'free' space is always valuable, and at a particular premium in the world of commercial publishing. Moreover if Springer retains the discretion to provide free access to journal content in the case of editorials, then there is a precedent for free access and it may be possible to expand its scope. In accepting this discretionary and promotional gift, and using it as we think best, we are finding and adapting resources for our own purposes. In a sense, the adaptation of gifts is an age-old feminist tactic of finding value in discretion and donation, and adding to that value by making the resource fit the need better. This 'adapting gifts' tactic works differently to a resignation, or withdrawl, tactic. Adapting gifts accepts the relation that produces the gift, but turns the gift into something else and does not perform some of the expectations that traditionally go along with gifting.

Many journals do not use editorials, and others use them to introduce content or to address a concern of the academic moment. They make different kinds of decisions about how to use the publisher's gift of free journal space, including nonuse, promotional use, and deliberative use. We have drawn on this diversity in editorial practice, but tried to do things in our own way. Sometimes we take hold of these online spaces with little in the way of gratitude because we do not see them as benevolent gifts, but as ours. Our work makes these spaces happen. We'll decide how to use them, including whether to use them at all.

Some editorials have discussed journal practices and events with a view to fleshing out the work of the journal. Others have introduced the content of the issue, but usually in connection with a concept - touchstones, comfort, vulnerability - that provides a sideways glance at the material, rather than an organizing drive, and

\footnotetext{
31 See https://www.glossa-journal.org.

32 For more information see https://www.journals.elsevier.com/lingua/. Accessed 30 July 2017.
} 
emanates from a reflexive encounter. Editorial boards everywhere find imaginative ways to engage with the world of publishing, but perhaps there is more we all could do to consider such engagement as ordinary research experience from a critical perspective. As Claire Hemmings is reported to have said at a recent panel on feminist journals, feminist journals are worthy sites of investigation as transnational networks. ${ }^{33}$ There is significant potential to do and say more with this in considering how kinship relations between authors, works and readers (Biagioli 2014), and arrangements of academic conduct between rightsholders, licencees and users, play out and may play differently as we 'adapt gifts' for our own purposes.

Our readers will have noticed that this issue is later than it normally is. We decided to experiment with 'stalling' and see what we could learn, and achieve, from holding back the compilation of the online issue and the publication of the print issue. Stalling is partly a way of \#ReclaimingMyTime, as Maxine Waters would say. Stalling tactics have also long been used by the governed as a way to sidestep someone else's timetable (see further Martin 1987, 140). At minimum, delaying submission of this editorial and compilation of the issue is a way of calling attention to the role of editorial contributions. The issue cannot go ahead with academic approval unless the academic editors participate in the process. We have continued doing the developmental work we do with authors and reviewers, and all accepted pieces have been published online as soon as their proofs have been approved. It is just the one final piece in choosing how the issue goes together and sending it off to production that we have delayed in a bid to flex our muscle a little and see if anyone pays attention.

The second reason we used stalling tactics this year was because, as it happens there were some developments, such as those in open access policy, to which we wanted to respond. And as the Women's Legal Landmarks project recorded FLS as a landmark (Auchmuty and Rackley 2016), we became conscious of the importance of recording our history differently, of acknowledging living history and speculations about what a FLS future might be. It seemed appropriate to use the best means available to us and take time to turn the editorial for issue 25.1 into something we wanted it to be.

Thirdly, we have been negotiating with Springer over revised contractual terms. Could disrupting the publisher's timetable and routine be a way of gaining more leverage? We have been given a minor increase in our stipend to cover meeting expenses, and a commitment to investigate better terms for APCs particularly in relation to reductions for scholars based in the Global South. But these are not enough and we are still unhappy with the lack of financial transparency over the journal's income and expenditure, and with the lack of substantive recognition for the academic labour we contribute. However, we have got to a point where we have learned some things, achieved some others, and want to move on ourselves, so we have finalized this editorial and compiled the first two issues of 2017. The other variable is that we have a new publishing editor, for the second time in two years.

\footnotetext{
33 "Clare Hemmings on the labour and love of producing feminist journals at the 13th Women's World, Brazil@FeministReview_@FeministTheory”, Tweet by @ srilaroy 31 July 20172.19 pm.
} 
We want to give that working relationship a fair try, even if staff turnover is a source of frustration.

Some of you may think it self-indulgent, unprofessional even, for us to act in this way. But we think it is a matter of being 'differently professional' in using the few tactics we have available to remind everyone, ourselves included, that academics can slow things down, and that we need to find ways to hold publishing processes to account. One concern obviously is whether a delay in issue compilation disadvantages our contributing authors. But as all the pieces are published online their work is accessible electronically and being downloaded. Another concern is that whatever the merit of the reasons for being late, being seen to be late may damage our reputation for reliability. Once the issues are out however, the lateness is visible from the publication dates, but not of any great significance as it's within the journal year. There are also other signifiers of reliability e.g. traffic about future submissions, impact factor, which are relatively strong. Now that we have found a way to say our piece, editorial energy can focus on other things and production decisions may be able to speed up. The stalling tactic has been useful, even partly pleasurable, but it also depletes our energy reserves. For issue 25.2 we will take a rest from negotiation and editorializing, and send the issue off without an editorial.

Rest and restoration are important wench tactics themselves of course. It is not just that resting is defiant and difficult in an environment which seems to demand continuous and enthusiastic engagement. And it is not just that much of what passes as 'rest' to patriarchal eyes is actually hard work in the form of social reproduction. Obviously, rest can have dimensions beyond the polarities of the so-called work/life balance. Rest tactics are also about stopping — or breaking the rhythm—in order to do something else. As we stopped and changed our usual rhythm for all the reasons outlined above we have taken time to remind ourselves why we do what we do.

Savouring the contributions to this issue as they offer up for engagement imagecontinuums, baraza, trials of protesters, asylum struggles, and not-so-timely reparations, has fed our critical reflections on openness and wench tactics. Writing this editorial has also allowed us to revisit FLaK as a scattering of intellectual ingredients. This scattering of FLaK, and repurposing of shrapnel, has potential as an alternative to linear approaches to knowledge generation and impact. It focuses instead on feminist methods of working with the pain and pleasure of where we are in our research arrangements as we strive to make other worlds out of what we have. The FLaK kitchen tables on 'getting the word out' gave us space to make our own of the dilemmas of open access policy and practice. In building on those insights and sharing our feminist hesitations over open access, we have sought to be critical of one-dimensional approaches to openness and accessibility under the sign of open access. Openness is not always good, and may hide closures which exhaust, swallow up or obfuscate. We have also taken time to explain how green open access, the SharedIt initiative, author request and publisher discretion, operate as alternative pathways to FLS content. And finally we have thought about the practice of wench tactics-withdrawing, adapting gifts, stalling and resting-in our publishing arrangements, and as they might be deployed elsewhere.

The brewing of editorial time (Grabham 2016), which allowed us to do these things, is our 25th birthday present to ourselves. Like many birthday presents, 
especially the ones we make for ourselves, brewing and stewing through our wench tactics have been ambivalent processes. They carry the trappings of celebration and enthusiasm, but might actually inhabit painful places. Maybe allowing ourselves to be grumpy with each other as we age, and occasionally difficult with those with whom we work, while taking care over the boundaries and workings of that grumpiness, provides a means of acknowledging those painful places, drawing on each other to find ways through, and taking pleasure in getting a wench's job done.

\section{References}

Ahmed, Sara. 2014. Living the consequences. Feminist Killjoys 3 January https://feministkilljoys.com/ 2014/01/03/living-the-consequences/ Accessed 10 July 2017.

Ahmed, Sara. 2004. The cultural politics of emotion. New York: Routledge.

Alessandrini, Donatella. 2011. Immaterial labour and alternative valorization processes in Italian debates: (re)-exploring the commons of reproduction Feminists@Law http://journals.kent.ac.uk/index.php/ feministsatlaw/article/view/32/98. Accessed 10 July 2017.

Ashiagbor, Diamond. 2006. Promoting precariousness? The response of EU employment policies to precarious work. In Precarious work, women and the new economy: The challenge to legal norms ed. Judy Fudge and Rosemary Owen. Oxford: Hart.

Auchmuty, Rosemary, and Erika Rackley. 2016. The Women's Legal Landmarks project: Celebrating 100 years of women in the law in the UK and Ireland. Legal Information Management 16 (1): 30-34. doi:10.1017/S1472669616000104.

Biagioli, Mario. 2014. Plagiarism, kinship and slavery. Theory, Culture and Society 31 (2/3): 65-91.

Blackett, Adele. 2016. What's informality got to do with it? Lecture at School of Law, SOAS, 27 July 2016. https://www.soas.ac.uk/law/events/27jul2016-whats-informality-got-to-do-with-it-domesticwork-the-employment-relationship-and-social-j.html.

Blackett, Adele. 2011. Special issue on regulating decent work for domestic workers. Canadian Journal of Women and the Law/Revue femmes et droit 23 (1): 1-358.

Brown, Wendy. 1993. Wounded attachments. Political Theory 21 (3): 390-410.

Cobb, Neil and Nikki Godden-Rasul. 2017. New research article on Campus Feminisms. Inherently Human. 28 April https://inherentlyhuman.wordpress.com/2017/04/28/new-research-article-campusfeminisms-cobb-godden-rasul/. Accessed 20 May 2017.

Cooper, Davina. 2015. Bringing the state up conceptually: Forging a body politics through anti-gay Christian refusal. Feminist Theory 16 (1): 87-107. doi:10.1177/1464700114562536.

Cooper, Davina. 2007. Opening up ownership: Community belonging, belongings and the productive life of property. Law and Social Inquiry 32 (3): 625-664. doi:10.1111/j.1747-4469.2007.00072.x.

Craig, Carys, Joseph T Turcotte and Rosemary Combe. 2011. What's feminist about open access? A relational approach to copyright in the academy. Feminists@Law 1(1) http://journals.kent.ac.uk/ index.php/feministsatlaw/article/view/7.

da Silva, Denise Ferreira. 2016. Fractal thinking. Accessions 2, 27 April. https://accessions.org/article2/ fractal-thinking/ Accessed 30 July 2017.

da Silva, Denise Ferreira. 2015. Hacking the subject: Black Feminism, refusal and the limits of critique. Barnard Centre for Research on Women, 22 October. http://bcrw.barnard.edu/videos/deniseferreira-da-silva-hacking-the-subject-black-feminism-refusal-and-the-limits-of-critique/. Accessed 30 July 2017.

Davidson, Helen. 2016. Reading the Nauru files: The people who took the story to the street. The Guardian. 29 December. https://www.theguardian.com/australia-news/2016/dec/29/reading-thenauru-files-the-people-who-took-the-story-to-the-streets.

Davies, Margaret. 2012. The law becomes us: Rediscovering judgment. Feminist Legal Studies 20: $167-181$. 
Deazley, Ronan and Jason Mathis. 2013. 'Writing about Comics and Copyright', CREATe Working Paper No. 9. www.create.ac.uk/wp-content/uploads/2013/12/CREATe-Working-Paper-No-9-v1.0. pdf. Accessed 10 July 2017.

Dunn, Hilary. 2017. The transitional justice gap: Exploring 'everyday' gendered harms and customary justice in South Kivu, DR Congo. Feminist Legal Studies. doi:10.1007/s10691-016-9335-7.

El-Enany, Nadine. 2017a. Racial and spatial injustices and the Tower Hamlets coup. In Spatial justice and diaspora, ed. Emma Patchett, and Sarah Keenan, 134-143. London: Counterpress.

El-Enany, Nadine. 2017b. The colonial logic of Grenfell. 3 July. https://www.versobooks.com/blogs/ 3306-the-colonial-logic-of-grenfell. Accessed 30 July 2017.

El-Enany, Nadine. 2016. Brexit as Nostalgia for Empire. Critical Legal Thinking. 19 June. http:// criticallegalthinking.com/2016/06/19/brexit-nostalgia-empire/. Accessed 30 July 2017.

El-Enany, Nadine and Sarah Keenan. 2016. \#NauruFilesReading: Articulating the violence of Australia's Refugee Policy. Critical Legal Thinking. 25 October. http://criticallegalthinking.com/2016/10/25/ nauru-files-reading/ Accessed 30 July 2017.

Enright, Máiréad. 2017. \#StrikeForRepeal: Ireland's Women's Strike. Critical Legal Thinking. 8 March 2017. http://criticallegalthinking.com/2017/03/08/strike4repeal-irelands-womens-strike/.

Enright, Máiréad. 2014. Sparing Enda's Blushes: Speaking of IMELDA and \#knickersforchoice. Human Rights in Ireland. http://humanrights.ie/constitution-of-ireland/sparing-endas-blushes-speaking-ofimelda-and-knickersforchoice/. Accessed 30 July 2017.

Federici, Silvia. 2012. Revolution at ground zero: Housework, reproduction and feminist struggle. New York: Common Notions.

Fightback, Feminist. 2011. Cuts are a feminist issue. Soundings 49: 73-83.

Fletcher, Ruth, Julie McCandless, Yvette Russell and Dania Thomas. 2016a. On Being Uncomfortable. Feminist Legal Studies 24(2): 121-126. https://link.springer.com/article/10.1007/s10691-016-93259.

Fletcher, Ruth, Julie McCandless, Yvette Russell, and Dania Thomas. 2016b. Internationalism and commitment at the kitchen table. Feminist Legal Studies 24 (1): 1-6. doi:10.1007/s10691-016-93188 .

Fletcher, Ruth. 2015a. FLaK: Mixing feminism, legality and knowledge. Feminist Legal Studies 23 (3): 241-252. doi:10.1007/s10691-015-9306-4.

Fletcher, Ruth. 2015b. Responding to submissions and introducing issue 23(1). Feminist Legal Studies 23 (1): $1-6$.

Franklin, Sarah. 2015. Sexism as a means of reproduction: Some reflections on the politics of academic practice. New Formations 86: 15-33. doi:10.3898/NewF.86.01.2015. https://www.lwbooks.co.uk/ sites/default/files/nf86_02franklin.pdf Accessed 30 July 2017.

Gallen, James. 2017. Review of Catherine Turner. Violence, law and the impossibility of transitional justice. Feminist Legal Studies. doi:10.1007/s10691-017-9338-z.

Gane, Nicholas. 2006. When we have never been human, what is to be done? Interview with Donna Harraway. Theory, Culture and Society 23 (7-8): 135-158.

Grabham, Emily. 2016. Brewing legal times: Things, form and the enactment of law. Toronto: University of Toronto Press.

Gunaratnam, Yasmin, and Carrie Hamilton. 2017. The wherewithal of feminism methods. Feminist Review 115 (1): 1-12.

Heyman, Tom, Pieter Moors, and Gert Storms. 2016. On the cost of knowledge: Evaluating the Boycott against Elsevier. Frontiers in Research Metrics and Analytics 1: 1-7. doi:10.3389/frma.2016.00007.

Hunter, Rosemary and Donatella Alessandrini. 2017. Why we still oppose gold and also oppose hybrid open access.Feminists@Law 6(2). http://journals.kent.ac.uk/index.php/feministsatlaw/article/view/ 350. Accessed 30 July 2017.

Jacob, Marie Andrée. 2017. Counterfeit, dexterity and publication ethics. In Beyond publish or perish: Metrics and the new ecologies of academic misconduct, ed. Mario Biagioli and Alexandra Lippman. Cambridge: MIT Press (forthcoming).

Jaschik, Scott. 2015. Language of protest. Inside Higher Education, 2 November. https://www. insidehighered.com/news/2015/11/02/editors-and-editorial-board-quit-top-linguistics-journalprotest-subscription-fees. Accessed 30 July 2017.

Jivraj, Suhraiya. 2016. The religion of law: Race, citizenship and children's belonging. Basingstoke: Palgrave Macmillan. 
Johnson, Janet Elise. 2014. Pussy Riot as a feminist project: Russia's gendered informal politics. Nationalities Papers: Journal of Nationalism and Ethnicity. 42 (4): 583-590. doi:10.1080/ 00905992.2014.916667.

Keenan, Sarah. 2017. A border on every street. The Disorder of Things. 29 June. https:// thedisorderofthings.com/2017/06/29/a-border-in-every-street/. Accessed 1 July 2017.

Keenan, Sarah. 2015. Subversive property: Law and the production of spaces of belonging. Abdingdon: Routledge.

Kelly, Liz. 1988. Surviving sexual violence. Cambridge: Polity Press.

Kember, Sarah. 2016. How open is open access? The Bookseller. 9 June. http://www.thebookseller.com/ blogs/how-open-open-access-333306. Accessed 30 July 2017.

Kember, Sarah. 2014. Why write? Feminism, publishing and the politics of communication. New Formations: A Journal of Theory/Culture/Politics 84: 99-116. doi:10.3898/NEWF.83.06.2014.

Kondakov, Alexander. 2017. The feminist citizen-subject: It's not about choice, it's about changing it all. Feminist Legal Studies. doi:10.1007/s10691-017-9341-4.

Lamble, Sarah. 2014. Twenty years of feminist legal studies: Reflections and future directions. Feminist Legal Studies 22 (2): 109-130. doi:10.1007/s10691-014-9266-0.

Lowe, Lisa. 2015. History hesitant. Social Text 33 (4): 85-107.

Mair, Jane. 2017. Review of Suhraiya Jivraj. The religion of law: Race, citizenship and children's belonging. Feminist Legal Studies. doi:10.1007/s10691-016-9333-9.

Manji, Ambreena and Peter Mandler. 2017. Budget wheeze could be double whammy for aid and research. Times Higher Education. 23 February. https://www.timeshighereducation.com/comment/ budget-wheeze-could-be-double-whammy-for-aid-and-research. Accessed 30 July 2017.

Martin, Emily. 1987. The woman in the body: A cultural analysis of reproduction. Boston: Beacon Press.

Mayer, Sophie. 2013. The size of a song: Pussy riot and the people power of poetry. Soundings 54: 146-160. doi:10.3898/136266213807299096.

McCandless, Julie, Mairead Enright, and Aoife O'Donoghue. 2017. Troubling judgment. In Northern/ Irish feminist judgments: Judges' troubles and the gendered politics of identity, ed. McCandless Enright, and O'Donoghue, 3-26. Oxford: Hart.

McGlynn, Claire, Erika Rackley, and Rachel Houghton. 2017. Beyond 'Revenge Porn': The continuum of image-based sexual abuse. Feminist Legal Studies. doi:10.1007/s10691-017-9343-2.

Mulcahy, Linda. 2015. Docile suffragettes: Resistance to police photography and the possibility of subjectobject transformation. Feminist Legal Studies 23 (1): 79-99. doi:10.1007/s10691-015-9280-x.

O'Donovan, Orla. 2014. The commons, the battle of the book and the cracked enclosures of academic publishing. Community Development Journal 49 (1): i21-i30. doi:10.1093/cdj/bsu021.

Petchesky, Rosalind. 1995. The body as property: A feminist revision. In Conceiving the new world order: The global politics of reproduction, ed. Faye Ginsburg, and Rayna Rapp, 387-424. Berkeley: University of California Press.

Rai, Shirin M., Catherine Hoskyns, and Dania Thomas. 2014. Depletion: The cost of social reproduction. International Feminist Journal of Politics 16 (1): 86-105. doi:10.1080/14616742.2013.789641.

Ramshaw, Sara. 2010. Jamming the law: Improvisational theatre and the 'Spontaneity' of Judgment'. Law, Text, Culture 14(1): 133-159. Available at: http://ro.uow.edu.au/ltc/vol14/iss1/9. Accessed 30 July 2017.

Research Information Network. 2008. Activities, costs and funding flows in the scholarly communications system. Available at: http://www.rin.ac.uk/our-work/communicating-and-disseminatingresearch/activities-costs-and-funding-flows-scholarly-commu. Accessed 30 July 2017.

Samuels, Hilary. 2017. Women asylum seekers in the current crisis: A conversation. Feminist Legal Studies. doi:10.1007/s10691-017-9346-z.

Spade, Dean. 2011. Laws as tactics. Columbia Journal of Gender and Law 21: 442-473.

Speaking of I.M.E.L.D.A. 2015. Dirty work still to be done: Retrieving and activating feminist acts of resistance. Contemporary Theatre Review. http://www.contemporarytheatrereview.org/2015/ margaretta-darcy/.

Stewart, Ann. 2011. Gender, law and justice in a global market. Cambridge: Cambridge University Press.

Thompson, Mary Shine. 2017. Doing feminist judgments. In Northern/Irish feminist judgments: Judges' troubles and the gendered politics of identity, ed. Mairead Enright, Julie McCandless, and Aoife O'Donoghue, 49-74. Oxford: Hart.

Tyler, Imogen. 2013. Naked protest: The maternal politics of citizenship and revolt. Citizenship Studies 17 (2): 211-226. doi:10.1080/13621025.2013.780742. 
Watson, Irene. 2015. Aboriginal peoples, colonialism and international law: Raw law. Abingdon: Routledge.

Welsh, Lucy. 2017. The role of law in temporal reasoning: An interview with Annelise Riles. Feminist Legal Studies. doi:10.1007/s10691-017-9340-5.

Working Group on Expanding Access to Published Research Findings (Finch Group). 2012. Accessibility, sustainability, excellence: How to expand access to research publications. Available here: https:// www.acu.ac.uk/research-information-network/finch-report. Accessed 30 July 2017. 